\title{
Mental Health of Farmers - Need of the Hour
}

\author{
Chitrasena Padhy ${ }^{1 *}$ and Pakalpati Satyanarayana Raju ${ }^{2}$
}

${ }^{1}$ PhD Student/Assistant Professor and ${ }^{2}$ Professor Adjunct

M.S. Swaminathan School of Agriculture, Centurion University of Technology and Management, Paralakhemundi-761 211, Odisha, India

*Corresponding author: chitrasenapadhy@cutm.ac.in (ORCID ID: 0000-0002-5611-1338)

Paper No. 821

Received: $12-10-2019$

Revised: 08-01-2020

Accepted: 21-02-2020

\begin{abstract}
Farmers are presently facing tough times. Farming is hard physical labour from morning to evening. Managing a farm can lead to monetary stress, anxiety, depression, financial ruin, marital strife, and addiction. The mental health message should reach not only to the farmers but also to the bankers, extension workers, counsellors and veterinarians. Farmers face a number of challenges when it comes to their mental health. Farming can create stress that can seriously impact the farmer's well being. Some of the behavioural signs due to stress in farming are loss of interest in social activities, poor concentration, confusion, forgetfulness, indecision, impatience in relationships, irritability, and withdrawal from society. Some of the physical symptoms are poor or disturbed sleep, weight loss or gain, changes in appetite, stomach upset, headache, and chest pain. In farms and rural areas issues of mental health are often ignored. The present is not an easy time to be in agriculture. Low commodity prices and mounting input costs are resulting in poor returns from farming. This has led to mental stress amongst farmers, which when unaddressed can lead to serious consequences in the farming community. Farmers and their families facing high levels of stress get into depression and even nourish suicidal thoughts. In rural areas, there is a paucity of mental health professionals who are culturally competent to serve farmers. In times of great stress, farmers need someone to talk to and get advice from. It can make all the difference in sorting out during troubled situations. Extension workers and advisors should understand the mental well being of farmers. Social activities must be encouraged and avenues for entertainment must be created in rural areas for farmers to get away from farm stress.

Highlights

(0 Agriculture as a stressful occupation is explained.

(0 Early diagnosis of mental health issues among farmers and timely measures to be taken are discussed.
\end{abstract}

Keywords: Behavioural signs, counsellors, farmer depression, farm stress, mental health

Farmers confront a number of mental health risks. Working long hours often in isolation, debt, financial pressure, overwhelming workload, bad weather, and natural disasters can seriously affect their livelihoods (Gifford 2019). According to an American Farm Bureau Federation (2019) study, more than $90 \%$ farmers said financial stress impacts their mental health. The University of Minnesota created a rural task force that connected farmers with resource persons, if they needed someone to talk with if they felt anxiety or stress (Lauritsen 2019).
When farmers are stressed, they need help and advice from agriculture professionals. Professionals such as veterinarians and agricultural extension workers, farmers' organizations, and rural support workers play an important role in supporting farmers in hard times. Health promotion campaigns could at times have a detrimental effect on some farmers during times of stress as continuously speaking to them about their mental health may increase their stress according to Massey University's College of Health. Agriculture professionals gain insight into the lives of farmers in good times as well as during 
times of stress and financial hardships (Nicke 2019). It was affirmed that farmers are reluctant to open up about their mental health issues as they perceive it as a sign of weakness (Fox 2019).

\section{Mental Health Perspectives in India}

Dongre and Deshmuhkh (2012) studying reasons for farmers' suicides in the Vidarbha region of Maharashtra found that farmers perceived debt, poor prices for farm produce, increased cost of cultivation, poor irrigation facilities, crop failure, governmental apathy, use of chemical fertilizers, and environmental pollution as the reasons for farmer suicides. Mitra and Shroff (2007) observed that the loss of the competitive edge of the Indian cotton farmer after the opening up of India's agricultural economy in the mid-1990s was a major reason for the increased farmer suicides.

Between January and June 2019, 1300 farmers died by suicide across Maharashtra (Mirror Now 2019). In Yavatmal districtof Vidarbha alone 139 farmers died by suicide. The Prerna Prakalp farmer counseling health service programme was launched by the government and accumulated the existing district mental health programme to address the mental illnesses that play a part in farmers' suicides. The local volunteers were trained as counsellors and go from village to village to help. Under this project accredited women social health activist volunteers work as health workers and are trained to detect common signs of mental illnesses by going through a 12-question survey.

Aggarwal (2008), a psychiatrist, concluded that farmers in India experience different stresses compared to farmers elsewhere, due to illiteracy, bonded labour system, large families, government corruption, and debts from local money lenders. A responsible farmer suicide task force must address both the biological and the broader social, cultural, political and economic issues. The onus should be shifted from the farmer to the circumstances.

Economic and weather uncertainties lead to farmers' suicides. The solution is to merge public policy initiatives with civil society engagements (Mishra 2006). Malone (2008) concludes that poverty, alcoholism, drought, and agrarian distress cause farmers' suicides. Jeromi (2007) argues that economic liberalization without safety nets along with droughts caused indebtedness which caused farmer suicides.

\section{Mental Health Perspectives in Other Countries}

People in the rural areas have limited access to health and mental healthcare services, which can make it difficult for farm and ranch families to receive support when they are experiencing extreme stress, anxiety, depression, or any other mental health crisis. It is due to poor mental health that the farmer would face difficult situation to manage other stressors that are common in their lives. Farmers, ranchers, and their families face high levels of stress, depression, and at times nurture even suicidal thoughts (Rural Health Information Hub, 2019). The mental health message needs to reach more of those in the agricultural community, not just the farmers but also bankers, extension workers, veterinarians, and counsellors. Data showing anxiety and depression are hard to get. During the Ag Media Summit, many nations' best communicators were told about the mental health needs of farmers and given an insight on how farmer stress can further damage an already wounded agricultural industry (Tipps 2019).

Life on the farm may appear for many non-farm people as a joy apart from the stress of living and working in urban and suburban areas. There appear to be no commuting nightmares, no time schedules, no deadlines, no bosses, and no production quotas. It looks like this attitude of farm life is from a simpler and more peaceful era, a time when people were more with nature and free from modern responsibilities. It is a romantic rural image cultivated by $19^{\text {th }}$ century artists, poets, and writers. Rosmann (2012), an adjunct faculty member at the University of Iowa and a psychologist, who founded Agri Wellness Inc., a non-profit programme that promotes behavioural health research on people affected by economic stresses involved in agriculture, reported suicide rate statistics of several occupations in the US, which shreds the myth of a stress-free life on the farm. The report indicated that individuals involved in agricultural careers including farmers, farm workers, lumber harvesters, ranchers, and fishers had the highest suicide rate of 84.5 per 100,000 people as per the study of 30 standard occupational classification groups The 
suicide rate for people working in agriculture was much higher than that of military veterans, which was 35.3 per 1,00,000 people. Rosmann observed that there are not enough behavioural health professionals who specialize in working with farm and ranch families. Roth (2017) reported that there are different stressors that farmers face and human beings react differently to stressful situations, while some people do well but others do not.

Guiney (2012) taking data from Victoria, Australia, during the prolonged drought from 2001 to 2007, concluded that farmer suicide rate increased during the period of drought. King et al. (2009) from studies in Australia observed that there were no significant differences between farmers and non-farmers in psychiatric morbidity and that accumulated stress resulting from a combination of factors contribute to farmer suicides. McLaren and Challis (2009) conducted a study on 99 Australian men farmers to investigate the applicability of three models of resiliency for the prediction of suicidal ideation from risk factor such as depression, protective factors such as social support and sense of belonging. They explored the role of social support and sense of belongingness as resilience factors for protection from suicide. A US study revealed a correlation between crop prices and the mental health of farmers (Barratt 2017). Crop prices steadily declined since 2012, leading experts to believe that farmers were the groups with increased risk of depression.

\section{Farmers at High Risk}

The struggles of the farming community are well documented with drought, flooding, disease, and poor crop yields. Often farmers must deal with stress, financial pressure, and difficult work conditions with little human contact for days leading to feeling of isolation. Male farmers are far less likely to discuss personal issues and often suffer in silences. A US study by the National Institute of Health suggested that use of pesticides, which can be inhaled or absorbed through skin, when used on crops is linked to an increased risk of depression (Barratt 2017).

\section{Recognized Issues in Other Jurisdictions}

1. More than one farmer a week in the UK dies by suicide (Swire 2018).
2. Research by Farm Safety Foundation within Great Britain revealed that $80 \%$ of young farmers (under 40) believe that mental health is the biggest problem facing farmers today, and $90 \%$ state that promoting good mental health is crucial for saving lives of farmers lives (https://www.yellowwellies.org/mindyour-head/).

3. A study on 84 English and Welsh farmers within Great Britain, who died by suicide, revealed that the most common single causal factor was mental health problems (Malmberg et al. 1999).

4. A study on the psychological morbidity of farmers and their spouses, based on 784 face to face interviews at agricultural shows, reported a higher risk of psychiatric disorders amongst farmers and their spouses compared to non-farmers (Hounsome et al. 2012).

5. A study on dairy farmers in New Zealand found prevalence of depression among dairy farmers was lower than in the general population but the anxiety disorder prevalence was higher (Botha and White 2013).

6. A 2015 national survey of the mental health of Canadian farmers revealed that $45 \%$ farmers were classified as having high levels of perceived stress and 35\% were classified as undergoing depression (Jones-Bitton 2015).

\section{Causes of Mental Health Issues Amongst Farmers}

Allen (2019) reported that the main causes for mental health issues amongst farmers were: solitary nature of work and social isolation, long working hours, lack of time off work, time pressures, record keeping and meeting regulatory requirements, aberrant weather, working with multi-generation family members, moving from running a family farm to running a business, lack of access to health and support services, financial worries because of income volatility and debt, hazardous working conditions, e.g. machinery, livestock, and chemicals, and the stigma associated with mental illness preventing people from seeking help. 


\section{Signals of Potential Mental Health Crisis in Farmers}

Murphree and Foster (2019) enumerated the signals emanating from farmers that may be used for diagnosing potential mental health crisis in farmers. These signals are decline in care of crops, animals and farm, deterioration in personal appearance, withdrawing from social events, family and friends, change in mood or routine, increase in farm accidents, giving away priced possessions, calling friends and relatives, making statements such as "I have nothing to live for" and "my family would be better off without me, I do not want to be a burden. Farmers generally manage stress in one of the four ways: (1) Figure, reassess and reassure: always figuring out how to make ends meet; it is going to be good if they can persuade themselves; they can persuade family and loan officers. (2) Distraction: By going and get parts for farm machinery, can ignore troubling issues, or take the day off. (3) Repression: eat, drink or do drugs. (4) Broaden and build: building positive reserves; when times come bad remember the good or fun times, go fishing or camping, or engage in recreational activities.

\section{Cultivating Productive Mindset}

Many factors are there in agriculture upon which farmers do not have any control. Besides uncertainty of weather, disease outbreaks, and machinery breakdown, one powerful factor is the mindset (Michigan State University Extension 2018). Having the right mindset can help increase productivity and resiliency, so that farmers are prepared to manage farms and families in tough times.

\section{Mindset Tactics}

\section{Use Self-Talk}

The body hears what the mind thinks. The farmers can tell themselves that they can overcome any challenge. They can adapt. They have come through rough times before. They can do it again. They can try using three words to tell themselves to help maintain the mindset, like calm, capable, and control.

\section{Use Breath}

When faced with a challenge, the farmers should use breath. Deep breathing calms the mind and can help to focus. It can reduce chronic pain and improve sleep. They should try breathing deep five times and releasing the air slowly and combine deep breathing with self-talk.

\section{Use Acceptance}

When things are out of the control, the most important thing is to accept it. Making acceptance as part of the mindset can save time and energy for focusing on the solution of the problem. They should try using the word acceptance part of their self talk and using deep breathing as a time to pause, accept and begin problem solving.

\section{Facts}

1. The typical brain is about $2 \%$ of the body weight but uses $20 \%$ of the energy (Jabr 2012).

2. Physical activity can help to lessen cortisol in the body and protect against negative impacts of stress (Hamer 2012; Puterman et al. 2012; Heaney et al. 2014)

\section{REFERENCES}

Barratt, S. 2017. Depression and anxiety are increasing among farmers and we need to do more for help. https://www. countryliving.com/uk/wellbeing/news/a2916/mentalhealth-depression-farmers/.

Botha, N., and White, T. 2013. Distress and burn out among NZ dairy farmers: research policy and recommendations, https:/www.researchgate.net/ publication/281078439Distress_and_burnout_among_NZ_ dairy_farmers/.

Dongre, A.R. and Deshmukh, P.R. 2012. Farmers' suicides in the Vidarbha region of Maharashtra, India: a qualitative exploration of their causes. J. of Injury and Violence Research, 4: 2-6.

Farm Safety Foundation, 2019. Mental health in agriculture. https://www.yellowwellies.org/ mind-your-head/

Fox, C. 2019. Farmers still have stigma about mental health issues. https://www.independent.ie/business/farming/ rural-life/farmers-still-have-stigma-about-mental-healthissues-37325040.html

Gifford, B. 2019. UK farmers open up about depression and mental health. https://happiful.com/uk-farmers-open-upabout-depression/

Guiney, R. 2012. Farming suicides during the Victorian drought: 2001-2007. Australian J. Rural Health, 20: 11-5.

Hamer, M. 2012. Psychosocial stress and cardiovascular disease risk: The role of physical activity. Psychosomatic Medicine, 74(9): 896-903. 
Heaney, J. L.J., Carroll, D. and Phillips, A.C. 2014. Physical activity, life events stress, cortisol, and DHEA: Preliminary findings that physical activity may buffer against the negative effects of stress. Journal of Aging and Physical Activity, 22: 465-473.

Hounsome, B., Rhiannon T.R., Hounsome N. and Gareth, E.J. 2011. Psychological morbidity of farmers and non-farming population: Results from a UK survey, https://www. researchgate.net/publication/51111932_Psychological_ Morbidity_of_Farmers_and_Non-farming_Population_ Results_from_a_UK_Survey

Indiaspend in India's suicide country, catching mental illness before it is too late, https://www.bloombergquint.com/ economy-finance/in-indias-suicide-country-catchingmental-illness-before-it-is-too-late.

Jabr, F. 2012. Does thinking really hard burn more calories? Scientific American. https:// www.scientific american.com/ article/thinking-hard-calories/

Jeromi, P.D. 2007. Impact of agricultural trade liberalisation: farmers' indebtedness and suicides in Kerala. Ind J. Agri. Econ., 62: 159-175.

Jones-Bitton, A. 2015. Agriculture and agri-food: Strengthening Canada's agricultural sector-A Canadian network for farmer mental health.

King, D., Lane, A., MacDougall, C. and Greenhill, J. 2009. The resilience and mental health and wellbeing of farm families experiencing climate variation in South Australia. Report for the National Institute of Labour Studies Incorporated, Adelaide, Australia.

Lauritsten, J. 2019. University of Minnesota Extension now offering mental health resources for farmers. https:// minnesota.cbslocal.com/2019/09/12/u-of-m-extensionnow-offering-mental-health-resources-for-farmers/

Malone, A. 2008. The GM genocide: Thousands of Indian farmers are committing suicide after using genetically modified crops. The Daily Mail. Available at http:// www.dailymail.co.uk/news/worldnews/article-1082559/ The-GM.

Malmberg, A., Simkin, S., Hawton, K. 1999. Suicide in farmers. British Journal of Psychiatry, 175: 103-105.

McLaren, S. and Challis, C. 2009. Resilience among Men Farmers: The Protective Roles of Social Support and Sense of Belonging in the Depression-Suicidal Ideation Relation. Death Studies, 33: 262-76.
Mark Allen. 2019. Farmers and mental health, https://www. assemblyresearchmatters.org/2019/05/15/farmers-andmental-health/

Michigan State University Extension. 2018. How to cultivate a productive mindset, https://www.canr.msu.edu/ resources/how_to_cultivate_a_productive_mindset.

Mishra, S. 2006. Farmers' Suicides in Maharashtra. Economic and Political Weekly, 41:1538-45.

Mitra, S. and Shroff, S. 2007. Farmers' Suicides in Maharashtra. Economic and Political Weekly, 42: 73-7.

Murphree Julie and Foster Liz. 2019. Tell-Tale Signs of a Mental Health Crisis for Farmers and Ranchers, https:// www.fb.org/view points/tell-tale-signs-of-a-mentalhealth-crisis-for-farmers-and-ranchers.

Neil, A. 2008. Farmer suicides in India: the role of psychiatry and anthropology. International J Social Psychiatry, 54: 291-2.

Newsroom. 2019. New National Poll shows Impacts of Rural Economy on Farmer Mental Health. https://www.fb.org/ newsroom/new-national-poll-shows-impacts-of-ruraleconomy-on-farmer-mental-health.

Puterman, E., O'Donovan, A., Adler, N.E., Tomiyama, A.J., Kemeny, M., Wolkowitz, O.M. and Epel, E. 2012. Physical activity moderates stressor-induced rumination on cortisol reactivity. Psychosomatic Medicine, 73(7): 604-611.

Roth, B.J. 2017. Mental health issues for farmers and their families often remain hidden. https://www.lancaster farming.com/farm_life/health_and_safety/mental-healthissues-for-farmers-and-their-families-often-remain/ article_79204eb3-a490-5fef-94a6-e98ab1659fe9.html

Stanley-Clarke Nicke. 2019. Agricultural professionals key in helping in farmer's mental health-research, https:// www.nzherald.co.nz/the-country/news/article.cfm?c id=16\&objectid=12240596

Swire John, 2018. More than one farmer a week in the UK dies by suicide, http://www.farmbusiness.co.uk/news/morethen-one-farmer-a-week-in-the-uk-dies-by-suicide-2.html

Tipps Ryan, 2019. Farmer mental health comes to the forefront as pressing rural need, https://www.agdaily.com/insights/ aaea-panelists-discuss-farmer-mental-health/ 
